\title{
METODE PEMBELAJARAN “MAKE A MATCH" DAN PENGARUHNYA TERHADAP HASIL BELAJAR IPA
}

\author{
Rina Hidayati Pratiwi \\ Pendidikan Biologi, FPMIPA, Universitas Indraprasta PGRI Jakarta \\ email: rina.hp2012@gmail.com
}

Diterima 12 Januari 2018 disetujui 20 April 2018

\begin{abstract}
Almost of unspecifically studying methods have been applied teacher for teaching activities. That methods have effected unefficiency for knowledge transferring to student. That is the reason how we need studying methods that efficient, creative and innovative. The purpose of this study is for knowing the studying methods "Make A Match" and how the impact to result study specifically for natural science. We use purpose sampling technics to definite research class and simple random sampling to definite part of sample of each class. The average score of experiment class are higher than control class. The different of both class is three point with normal distribution for each class and from homogeneity test showed that $F$ hit $=1,163$. Both of them have homogeneous varians. The average point of experiment class are higher than control class too. T-test showed $t$ hit $>$ t table $(3,614>1,69)$. Thus, the studying methods "Make a Match" could raised the study results better than conventional methods. As the result, the quality of education can be more improved agree with contain and the purpose of studying in the school.
\end{abstract}

Keywords : Make a match, Natural sciences, Studying methods

\section{PENDAHULUAN}

Pembelajaran adalah proses belajar yang dibangun guru untuk mengembangkan kreativitas berpikir yang dapat meningkatkan kemampuan berpikir siswa, serta dapat meningkatkan kemampuan mengkonstruksi pengetahuan baru sebagai upaya peningkatan penguasaan yang baik terhadap materi pelajaran. Proses pembelajaran yang efektif dan kondusif akan terjadi jika guru mampu memilih dan menggunakan strategi pembelajaran yang tepat serta didukung oleh metode dan pendekatan pembelajaran yang variatif dan inovatif. Metode pembelajaran yang variatif dan inovatif dapat menghilangkan kejenuhan siswa dan meningkatkan perhatian siswa terhadap pelajaran sehingga akan diperoleh hasil belajar yang maksimal.

Jenjang pendidikan SMK yang merupakan sekolah kejuruan memiliki perbedaan dengan jenjang pendidikan SMA dalam hal materi ajar. Materi ajar di
SMK lebih banyak aplikasi dibandingkan materi ajar di SMA yang membutuhkan banyak penjelasan (teori) di kelas terutama pada mata pelajaran IPA. Materi ajar di SMK juga lebih sedikit dibandingkan di SMA, sehingga di SMK cenderung mengacu pada pengaplikasian di lingkungan.

Metode pengajaran yang ditemukan di lapangan menunjukkan bahwa metode pengajaran yang diterapkan di sekolah masih menggunakan metode pembelajaran konvensional yang berpusat pada guru. Guru aktif menjelaskan sedangkan siswa bersifat pasif yang hanya mendengarkan penjelasan dari guru. Kurangnya keaktifan siswa di dalam kelas disebabkan oleh pemilihan dan penerapan metode pembelajaran yang tidak sesuai. Kondisi pembelajaran menyebabkan penyampaian materi oleh guru dapat menimbulkan rasa bosan bagi siswa sehingga siswa akan kesulitan untuk berkonsentrasi dan tidak fokus terhadap 
materi yang dipelajari saat itu. Akibatnya hanya sedikit materi pembelajaran yang dapat dipahami oleh siswa dan bahkan tidak benar-benar ada yang dipahami.

Berlatar belakang masalah tersebut, maka perlu dilakukan pengembangan pengetahuan siswa melalui penerapan metode pembelajaran yang kreatif dan inovatif. Metode pembelajaran yang kreatif dimaksudkan agar siswa mampu melakukan eksplorasi terhadap dunia sekitar dengan menggali informasi melalui berbagai sumber pembelajaran dan pengetahuan yang diperoleh secara mandiri.

Salah satu metode pembelajaran inovatif adalah "Make a Match" atau mencari pasangan dikembangkan oleh Lorna Curran. Menurut Curran yang dikutip oleh Suprijono (2009), metode "Make a Match" merupakan metode mencocokkan kartu, siswa harus mencari pasangan dari kartu yang dimiliki dengan batas waktu tertentu mengenai suatu konsep pelajaran dalam suasana yang menyenangkan. Berdasarkan pernyataan tersebut, metode pembelajaran "Make a Match" digunakan untuk mengukur pemahaman siswa, yang dilakukan dengan cara mencocokkan kartu yang berisi pertanyaan dan jawaban dari materi pembelajaran yang sudah diajarkan.

Metode pembelajaran "Make a Match" merupakan bagian dari strategi pembelajaran yang dapat meningkatkan kemampuan kognitif siswa. Metode pembelajaran tersebut mengajak siswa untuk dapat menghafal atau mengingat materi pelajaran dengan cara yang baru dan menyenangkan. Metode pembelajaran "Make a Match" dapat membantu kesulitan belajar siswa terutama dalam hal mengingat materi pelajaran. Proses pembelajaran dengan menggunakan metode pembelajaran lebih inovatif "Make a Match" dapat berorientasi pada aktivitas belajar siswa menjadi lebih bermakna, lebih berorientasi pada keaktifan, serta membantu meningkatkan proses dan hasil belajar. Tujuan dari studi ini ialah untuk mengidentifikasi keuntungan yang diperoleh oleh siswa dari penerapan metode pembelajaran "Make a Match" terhadap hasil belajar siswa pada pelajaran IPA. Rata-rata kemampuan bernalar ilmiah pada siswa non-sains lebih tinggi dibandingkan siswa sains. Kondisi kemampuan menalar ilmiah pada siswa non sains lebih tinggi dibandingkan siswa sains terlihat dari jawaban pertanyaan yang diberikan pada siswa sains cenderung satu jawaban tanpa disertai alasan mengapa mereka memilih jawaban tersebut. Jika ada alasan yang diminta, siswa sains hanya menuliskan ulang kalimat penjelas yang ada pada kotak pilihan (Asniar 2015). Dipilihnya metode pembelajaran "Make a Match" sebagai bagian dari strategi pembelajaran dengan harapan dapat meningkatkan kemampuan kognitif siswa sains atau siswa yang mempelajari mata pelajaran IPA.

Beberapa penelitian relevan sudah dilakukan diantaranya oleh Astika (2012) terhadap siswa tingkatan SMAN di Semarang yang membuktikan bahwa penerapan metode pembelajaran kooperatif tipe "Make a Match" dapat meningkatkan hasil belajar siswa dan lebih efektif jika dibandingkan dengan metode pembelajaran konvensional. Berdasarkan eksperimen yang dilakukan oleh Mulyarsih (2010) dan Lingga (2012) terhadap siswa SDN di Batang, Jawa Tengah dan Pekan Baru, Riau menunjukkan bahwa penerapan metode pembelajaran "Make a Match" dapat meningkatkan aktivitas belajar siswa serta dapat meningkatkan hasil belajar pada mata pelajaran IPA dan IPS dibandingkan dengan metode pembelajaran konvensional. 


\section{METODE}

Penelitian ini menggunakan metode kuantitatif dalam pengambilan data, pengumpulan data hingga memperoleh hasil datanya yang diperoleh dalam bentuk skor (angka). Teknik sampling yang digunakan ialah teknik purpose sampling untuk menentukan kelas penelitian dan teknik simple random sampling untuk menentukan anggota sampel dari tiap kelas.

Berdasarkan tujuan dan perumusan masalah penelitian di atas, maka jenis penelitian yang digunakan adalah penelitian eksperimen semu. Penelitian yang menggunakan eksperimen semu, yaitu dengan memberikan jenis perlakuan yang berbeda pada dua kelompok belajar siswa di salah satu sekolah menengah di Jakarta dengan total sebanyak 75 siswa. Masingmasing kelas diambil 20 siswa secara acak sehingga total sampel adalah 40 siswa. Kelompok yang satu dijadikan sebagai kelompok eksperimen yaitu kelompok yang diberikan perlakuan menggunakan metode pembelajaran "Make a Match", sedangkan kelompok lainnya sebagai kelompok kontrol yang diberikan perlakuan dengan menggunakan metode pembelajaran konvensional berupa metode diskusi. Pada kedua kelompok belajar tersebut diberikan tes yang sama. Hasil dari tes tersebut dijadikan data penelitian dan dianalisis.

Metode Quasi Eksperimen digunakan untuk menganalisis data, sedangkan untuk pengujian hipotesis menggunakan Uji-T yang sebelumnya telah dilakukan uji normalitas menggunakan uji Liliefors dan uji homogenitas menggunakan Fisher.

\section{HASIL DAN PEMBAHASAN}

Menurut Curran yang dikutip oleh Suprijono (2009) dan Lie (2010), langkah-langkah penerapan metode pembelajaran "Make a Match" antara lain guru menyiapkan beberapa kartu yang berisi beberapa konsep atau topik yang cocok untuk sesi review, satu bagian kartu soal dan bagian lainnya berupa kartu jawaban lalu setiap siswa mendapatkan sebuah kartu yang bertuliskan soal atau jawaban kemudian setiap siswa memikirkan jawaban atau soal dari kartu yang dipegang selanjutnya setiap siswa mencari pasangan kartu yang cocok dengan kartunya, dan setiap siswa yang dapat mencocokkan kartunya sebelum batas waktu akan diberi poin. Jika siswa tidak dapat mencocokkan kartunya dengan kartu temannya (tidak dapat menemukan kartu soal atau kartu jawaban) maka akan mendapatkan hukuman yang telah disepakati bersama. Setelah satu babak, kartu dikocok lagi agar setiap siswa mendapat kartu yang berbeda dari sebelumnya, demikian seterusnya. Siswa juga bisa bergabung dengan 2 atau 3 siswa lainnya yang memegang kartu yang cocok. Terakhir, guru bersama-sama dengan siswa membuat kesimpulan terhadap materi pelajaran.

Menurut Aqib (2013), penerapan metode pembelajaran "Make a Match" dilakukan dengan cara mencari jawaban dari kartu yang dimiliki siswa yang berisi suatu materi pembelajaran tertentu. Langkah-langkah penerapan metode "Make a Match" antara lain: guru menyiapkan beberapa kartu yang berisi beberapa konsep atau topik pelajaran tertentu dimana terdiri atas kartu soal dan kartu jawaban lalu setiap siswa diharuskan mencari pasangan kartu yang cocok dengan kartunya dalam batas waktu tertentu. Setiap siswa yang dapat mencocokkan kartunya sebelum batas waktu akan diberi poin. Lalu setelah satu babak kartu dikocok lagi agar setiap siswa mendapat kartu yang berbeda dari sebelumnya. Tahapan terakhir, guru bersama-sama dengan siswa membuat 
kesimpulan terhadap materi pelajaran. Adapun hasil penelitian dalam distribusi frekuensi kelas eksperimen seperti pada Tabel 1. Berdasarkan Gambar 1 tentang histogram dan poligon hasil belajar siswa kelas eksperimen, dapat disimpulkan bahwa nilai tertinggi berada pada interval
89,5-94,5 dengan jumlah siswa sebanyak 5 orang, sedangkan untuk nilai terendah berada pada interval 64,5-70,5 dengan jumlah siswa sebanyak 1 orang. Adapun jumlah siswa terbanyak berada pada nilai interval 76,5-82,5 dengan jumlah siswa sebanyak 8 orang.

Tabel 1. Distribusi frekuensi kelas eksperimen

\begin{tabular}{|l|l|l|l|l|l|l|l|l|l|}
\hline $\begin{array}{c}\text { Kelas } \\
\text { Interval }\end{array}$ & $f i$ & $x i$ & $f r$ & $f \%$ & $<\left(f k u m^{*}\right)$ & $>\left(f k u m^{* *}\right)$ & $f i . x i$ & $(x i-x)^{2}$ & $f(x i-x)^{2}$ \\
\hline $65-70$ & 1 & 67,5 & 0,05 & 5 & 1 & 20 & 67,5 & 210,25 & 210,25 \\
\hline $71-76$ & 3 & 73,5 & 0,15 & 15 & 4 & 19 & 220,5 & 72,25 & 216,75 \\
\hline $77-82$ & 8 & 79,5 & 0,4 & 40 & 12 & 16 & 636 & 6,25 & 50 \\
\hline $83-88$ & 3 & 85,5 & 0,15 & 15 & 15 & 8 & 256,5 & 12,25 & 36,75 \\
\hline $89-94$ & 5 & 91,5 & 0,25 & 25 & 20 & 5 & 457,5 & 90,25 & 451,25 \\
\hline$\Sigma$ & $\mathbf{2 0}$ & & $\mathbf{1}$ & $\mathbf{1 0 0}$ & & & & & \\
\hline
\end{tabular}

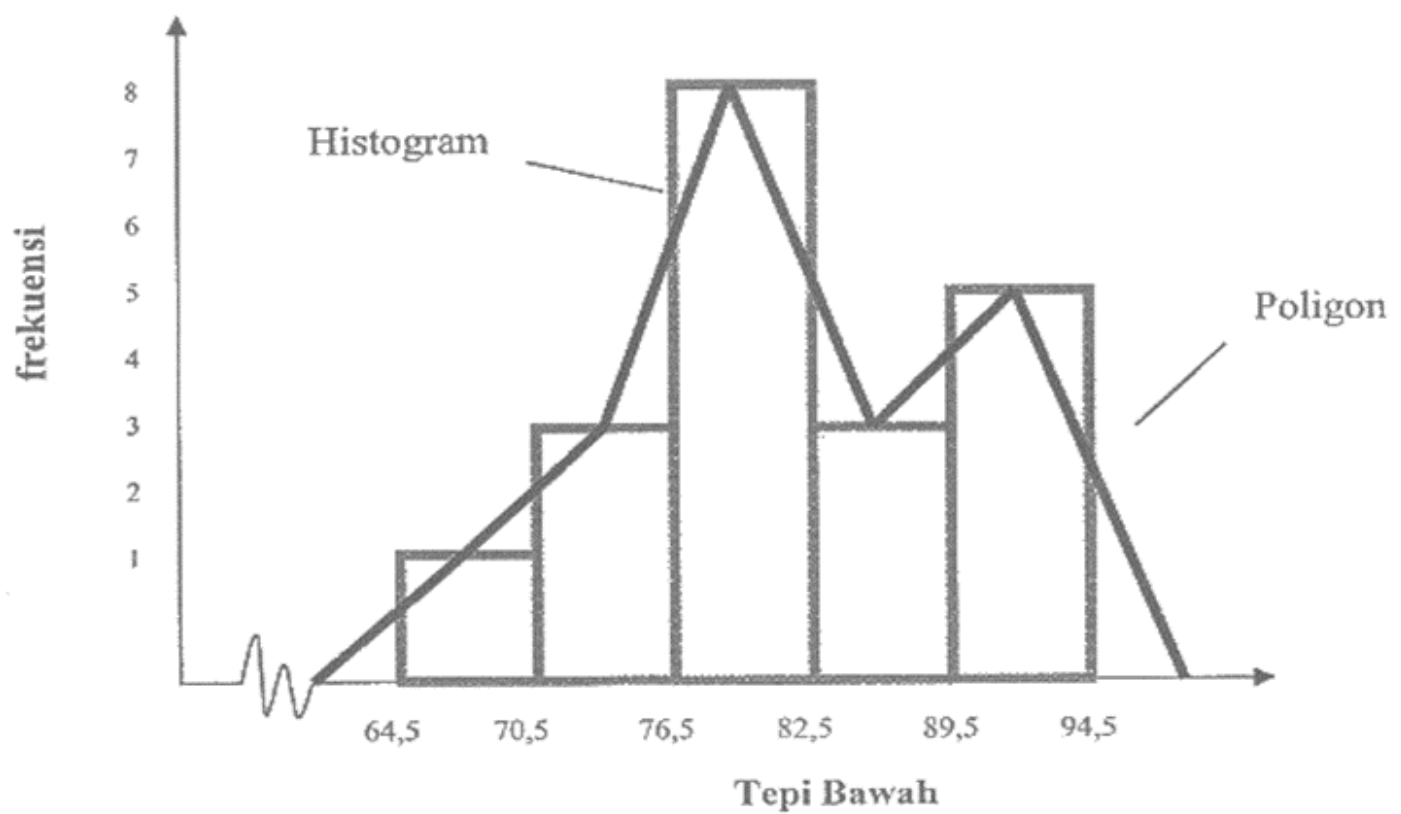

Gambar 1. Histogram dan Poligon Hasil Belajar Siswa Kelas Eksperimen

Berdasarkan Gambar 2 tentang histogram dan poligon hasil belajar siswa kelas kontrol, dapat disimpulkan bahwa nilai tertinggi berada pada interval 87,592,5 dengan jumlah siswa sebanyak 3 orang, sedangkan untuk nilai terendah berada pada interval 67,5-72,5 dengan jumlah siswa yang sama sebanyak 3 orang. Adapun jumlah siswa terbanyak berada pada nilai interval 72,5-77,5 dengan jumlah siswa sebanyak 7 orang. 
Dari hasil perhitungan tersebut dapat diketahui bahwa skor rata-rata kelas eksperimen lebih tinggi daripada kelas kontrol yaitu memiliki selisih 3,0 dengan data masing-masing kelas berdistribusi normal dan dari hasil perhitungan uji homogenitas dapat diketahui $\mathrm{F}$ hitung sebesar 1,163. Oleh karena itu, kedua data tersebut mempunyai varians yang homogen.

Diketahui dari hasil perhitungan bahwa nilai rata-rata kelas eksperimen lebih tinggi dibandingkan rata-rata kelas kontrol, diperkuat lagi dengan pengujian hipotesis menggunakan Uji-t yang diketahui hasilnya nilai $\mathrm{t}$ hitung > t tabel $(3,614>1,69)$. Ho ditolak yang berarti hasil belajar dengan metode pembelajaran "Make a Match" lebih tinggi dibandingkan hasil belajar dengan metode pembelajaran konvensional. Dari berbagai eksperimen, juga menunjukkan bahwa hasil belajar siswa yang mengikuti metode pembelajaran "Make a Match" lebih tinggi dibandingkan dengan siswa yang mengikuti metode pembelajaran konvensional. Dalam pelaksanaannya, berdasarkan penelitian Nurlia Astika (2012) yang menerapkan metode tersebut di kelas XI IPA pada tingkatan SMA.

Tabel 2. Distribusi Frekuensi Kelas Kontrol

\begin{tabular}{cccccccccc}
\hline $\begin{array}{c}\text { Kelas } \\
\text { Interval }\end{array}$ & $f i$ & $x i$ & $f r$ & $f \%$ & $<\left(f k u m^{*}\right)$ & $>\left(f k u m^{* *}\right)$ & $f i . x i$ & $(x i-x)^{2}$ & $f(x i-x)^{2}$ \\
& & & & & & & & & \\
\hline $68-72$ & 3 & 70 & 0,35 & 35 & 3 & 20 & 210 & 81 & 243 \\
$73-77$ & 7 & 75 & 0,15 & 15 & 10 & 17 & 525 & 16 & 112 \\
$78-82$ & 4 & 80 & 0,20 & 20 & 14 & 10 & 320 & 1 & 4 \\
$83-87$ & 3 & 85 & 0,15 & 15 & 17 & 6 & 255 & 36 & 108 \\
$88-92$ & 3 & 90 & 0,15 & 15 & 20 & 3 & 270 & 121 & 363 \\
& & & & & & & & \\
\hline$\Sigma$ & $\mathbf{2 0}$ & & $\mathbf{1 0 0}$ & & & & & & \\
\hline
\end{tabular}

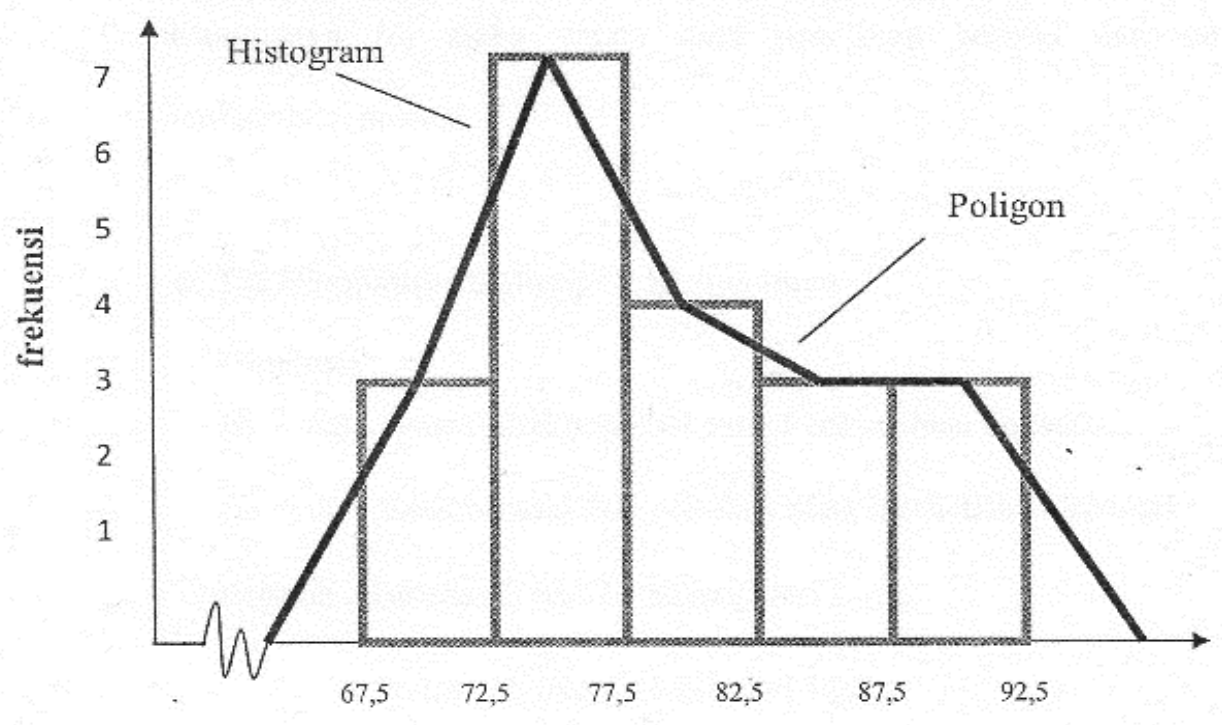

Tepi Bawah

Gambar 2. Histogram dan Poligon Hasil Belajar Siswa Kelas Kontrol 
Berdasarkan tabel 2, diperoleh data rata-rata hasil belajar kelas eksperimen adalah 41,16. Sementara hasil belajar pada kelompok kontrol rataratanya adalah 36,83. Hal tersebut menunjukkan bahwa nilai rata-rata kelas eksperimen lebih tinggi dibandingkan rata-rata kelas kontrol.

Menurut Curran yang dikutip oleh Suprijono (2012) menyatakan bahwa metode pembelajaran "Make a Match" merupakan metode pembelajaran alternatif untuk mengukur pemahaman siswa, yang dilakukan dengan cara mencocokkan kartu berisi pertanyaan dan jawaban mengenai suatu konsep pelajaran dalam suasana pembelajaran yang menyenangkan. Metode pembelajaran "Make a Match" mempunyai penerapan yang berbeda dari metode pembelajaran konvensional, sehingga dapat disesuaikan dengan kebutuhan siswa dan suasana kelas secara berkelompok (Aprilia, 2013).

Berdasarkan hasil penerapan praktik di lapangan, ternyata metode pembelajaran "Make a Match" mempunyai beberapa kelebihan, diantaranya metode pembelajaran tersebut mampu menciptakan suasana belajar yang aktif dan menyenangkan, materi pembelajaran yang disampaikan menjadi lebih menarik perhatian siswa sehingga mampu meningkatkan hasil belajar siswa mencapai taraf ketuntasan belajar secara klasikal 87,50\%, kerjasama antar sesama siswa juga dapat terwujud dengan dinamis, serta munculnya dinamika gotong-royong yang merata di seluruh siswa.

Penerapan metode pembelajaran "Make a Match" diharapkan dapat menumbuhkan keaktifan siswa dalam pembelajaran dengan suasana yang menyenangkan dan inovatif. Berdasarkan hasil eksperimen tersebut, maka metode pembelajaran "Make a Match" dapat dijadikan salah satu alternatif pembelajaran di kelas sehingga membuat proses pembelajaran lebih bermakna dan menyenangkan (Inayah, 2010).

\section{SIMPULAN}

Dari berbagai eksperimen dapat disimpulkan bahwa terdapat pengaruh positif pada metode pembelajaran "Make A Match" terhadap hasil belajar IPA sehingga dapat dijadikan sebagai metode pembelajaran alternatif. Metode ini dilakukan untuk menjawab pertanyaan yang terkait dengan suatu materi pelajaran dengan cara mencocokkan kartu. Cara-cara dalam metode "Make A Match" bertujuan menumbuhkan keaktifan siswa dalam pembelajaran dengan suasana yang menyenangkan serta memupuk kerjasama siswa dalam menjawab pertanyaan bersama-sama.

\section{DAFTAR PUSTAKA}

Aqib, Z. (2013). Model-Model, Media, dan Strategi Pembelajaran Kontekstual. Bandung: Yrama Widya.

Asniar. (2016). Profil Penalaran Ilmiah dan Kemampuan Berargumentasi Mahasiswa Sains dan Non-Sains. Jurnal Penelitian dan Pembelajaran IPA. 2 (1): 30-41.

Astika, N. (2012). Efektivitas Metode Pembelajaran Kooperatif Tipe Make A Match terhadap Hasil Belajar Siswa Kelas XI IPA 5 SMAN 2 Semarang Tahun Pelajaran 2011/2012.

Inayah, N. (2010). Peningkatan Keaktifan dalam KBM dan Prestasi Belajar Peserta Didik Melalui Teknik Pembelajaran Mencari Pasangan (Make a Match) diSMK Negeri 1 Sedayu. (online),

Lie, A. (2010). Cooperative Learning: Mempraktikkan Cooperative Learning di Ruang Kelas. Jakarta: Gramedia. 
Lingga, L.J. (2012). Penerapan Model

Pembelajaran Kooperatif Tipe Make A Match untuk

Meningkatkan Hasil Belajar IPS

Siswa Kelas IV SDN 18, Pekanbaru.

Mulyarsih. (2010). Peningkatan Hasil

Belajar IPS Melalui Metode

Pembelajaran Kooperatif Tipe

Make a Match pada Siswa

Kelas IV SDN Harjowinangun 01,

Suprijono, A. (2009). Cooperative

Learning. Yogyakarta:

Pustaka Belajar. 